\section{Evaluation of Experimental Bermudagrasses under Simulated Athletic Field Traffic with Perennial Ryegrass Overseeding}

\author{
William D. Haselbauer ${ }^{1,3}$, Adam W. Thoms ${ }^{1,4,8}$, \\ John C. Sorochan ${ }^{1,5}$, James T. Brosnan ${ }^{1,6}$, Brian M. Schwartz ${ }^{2,6}$ \\ and Wayne W. Hanna ${ }^{2,7}$
}

AdDitional INDEX wORDs. Cynodon dactylon $\times$ C. transvaalensis, Cady traffic simulator, grooming, football

Summary. Hybrid bermudagrass (Cynodon dactylon $\times$ C. transvaalensis) varieties such as Tifway and TifSport commonly are used on athletic fields. Several experimental hybrid bermudagrasses have been recently developed. However, data describing the performance of these bermudagrasses under simulated athletic field traffic are limited. A 2-year study was conducted evaluating the traffic tolerance of five experimental (2004-76, 2004-83, 2004-78, Tift 11, and 2004-77) and three commercially available ('Tifway', 'TifSport', and 'TifGrand') hybrid bermudagrasses. These bermudagrasses were subjected to two mowing (mowing at $\mathbf{0 . 8 7}$ inches or mowing at 0.87 inches + grooming to a 0.10 -inch depth) and overseeding [no overseeding or overseeding with perennial ryegrass (Lolium perenne) at $12 \mathrm{lb}$ / $1000 \mathrm{ft}^{2}$ of pure live seed] regimes. Simulated traffic tolerance using the Cady traffic simulator (CTS) was quantified using measurements of turfgrass cover with digital image analysis (DIA). Experimental bermudagrasses Tift 11 and 2004-76 and the commercially available variety TifGrand yielded turfgrass cover values greater than or equal to 'Tifway', a commonly used variety, on all rating dates each year. Experimental bermudagrass 2004-83 yielded the lowest turfgrass cover values on each date. Findings suggest that 'TifGrand', 2004-76, and Tift 11 may be suitable for use on athletic fields.

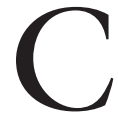
ommon bermudagrass (Cynodon dactylon) and hybrid bermudagrass are the most common turfgrasses used on athletic fields in the transition zone [a zone extending through the central part of the United States in which the winters are too cool for warm-season turfgrasses and the summers are too warm for the cool-season turfgrasses (Christians, 1998)] because of its recuperative potential and ability to tolerate high temperature extremes during summer (McCarty et al., 2005). Turfgrass breeders regularly develop experimental bermudagrasses for improved

\footnotetext{
${ }^{1}$ Department of Plant Sciences, University of Tennessee, 252 Ellington Plant Sciences Building, 2431 Joe Johnson Drive, Knoxville, TN 37996

${ }^{2}$ Department of Crop and Soil Science, University of Georgia, P.O. Box 748, Tifton, GA 31794

${ }^{3}$ Graduate Student

${ }^{4}$ Research Leader

${ }^{5}$ Associate Professor

${ }^{6}$ Assistant Professor

${ }^{7}$ Professor

${ }^{8}$ Corresponding author. E-mail: athoms@utk.edu.
}

performance. One such variety, TifGrand (previously experimental line ST-5 and Tift No. 4), was recently developed to offer improved shade tolerance compared with hybrid bermudagrass varieties such as Tifway and TifSport (Baldwin et al., 2008; Hanna et al., 2010). Although turfgrass breeders thoroughly evaluate the quality, density, color, disease resistance, and cold tolerance of these experimental bermudagrasses before introducing them into the marketplace, information on the traffic tolerance of these selections is often limited (W.W. Hanna, personal communication).

Athletic Field traffic. Traffic is an action that inflicts plant wear and soil compaction. Turfgrass wear is defined as injury due to direct pressure that mechanically damages leaves, stems, and crowns (Beard, 1973). Soil compaction is characterized by a change in soil physical properties that adversely affects turfgrass growth (Cockerham and Wiecko, 1989). Cockerham (1989) reported that the majority of traffic on a football field occurs between the 40yard lines, spanning the width of the hash marks [6.2 yards for the National Football League and 13.3 yards for the National Collegiate Athletic Association (NCAA)].

The traffic tolerance of commercially available seeded and vegetative hybrid bermudagrasses has been evaluated. Goddard et al. (2008) reported that 'Tifway' and 'Riviera' exhibited better traffic tolerance than 'Quickstand', using the CTS developed by Henderson et al. (2005). Deaton and Williams (2010) reported a similar response using the Brinkman traffic simulator (BTS) as well. Trappe et al. (2009) reported that 'Riviera', Tift No. 4, and 'Tifway' exhibited the best traffic tolerance in a study of 42 bermudagrasses using the CTS. When comparing varieties of seashore paspalum (Paspalum vaginatum) to hybrid bermudagrass, Brosnan and Deputy (2009) reported that the traffic tolerance of 'Tifway' was greater than or equal to seashore paspalum varieties Sea Dwarf, Sea Isle 1, Sea Isle 2000, and Salam. Trenholm et al. (1999) also reported that 'Tifway' was comparable in wear tolerance and recovery to seven seashore paspalum varieties in Georgia. These results indicate that 'Tifway' is an ideal candidate for use as a

\begin{tabular}{llll}
\hline $\begin{array}{l}\text { Units } \\
\begin{array}{l}\text { To convert U.S. to SI, } \\
\text { multiply by }\end{array}\end{array}$ & U.S. unit & SI unit & $\begin{array}{l}\text { To convert SI to U.S., } \\
\text { multiply by }\end{array}$ \\
\hline 0.3048 & $\mathrm{ft}$ & $\mathrm{m}$ & 3.2808 \\
0.0929 & $\mathrm{ft}^{2}$ & $\mathrm{~m}^{2}$ & 10.7639 \\
2.54 & inch(es) & $\mathrm{cm}$ & 0.3937 \\
25.4 & inch(es) & $\mathrm{mm}$ & 0.0394 \\
645.1600 & inch & $\mathrm{mm}^{2}$ & 0.0016 \\
4.8824 & lb $/ 1000 \mathrm{ft}^{2}$ & ${\mathrm{~g} \cdot \mathrm{m}^{-2}}^{-1}$ & 0.2048 \\
48.8243 & lb/1000 $\mathrm{ft}^{2}$ & $\mathrm{~kg} \cdot \mathrm{ha}^{-1}$ & 0.0205 \\
1.1209 & lb/acre & $\mathrm{kg} \cdot \mathrm{ha}^{-1}$ & 0.8922 \\
4.4482 & lbf & $\mathrm{N}$ & 0.2248 \\
0.9144 & yard(s) & $\mathrm{m}$ & 1.0936 \\
$\left({ }^{\circ} \mathrm{F}-32\right) \div 1.8$ & ${ }^{\circ} \mathrm{F}$ & ${ }^{\circ} \mathrm{C}$ & $\left(1.8 \times{ }^{\circ} \mathrm{C}\right)+32$
\end{tabular}


commercial standard when evaluating the traffic tolerance of experimental bermudagrasses.

HYBRID BERMUDAGRASS MANAGEMENT ON ATHLETIC FIELDS. Vertical mowing, grooming, and overseeding are common practices used to maintain hybrid bermudagrass (Dunnivant, 2008; Kopec et al., 2005; McCarty et al., 2007; Westmoreland et al., $2007)$. Vertical mowing is a process in which blades, mounted on a horizontal shaft rotating on a vertical plane, penetrate the turf surface to remove grain, reduce thatch, and stimulate shoot development (Duble, 1996; Dunnivant, 2008). Grooming, a less invasive form of vertical mowing (blades typically penetrate less than $3.8 \mathrm{~mm}$ into the turf canopy), has been used to improve mowing quality and promote adventitious shoot growth from stolons (McCarty et al., 2005 ). Overseeding is the process of establishing a cool-season turfgrass into a semi or fully dormant stand of bermudagrass to increase athletic field aesthetic and functional quality during late fall and winter (Cockerham et al., 1993; Mazur and Wagner, 1987). Thoms et al. (2011) reported frequent grooming may reduce traffic tolerance in both hybrid and common bermudagrass, whereas overseeding with perennial ryegrass may actually protect the bermudagrass from the negative effects of traffic. To determine the suitability of experimental bermudagrasses for use on athletic fields, it is important to evaluate their responses to traffic when maintained using common maintenance practices such as vertical mowing, grooming, and overseeding.

Research evaluating the effects of vertical mowing, grooming, and overseeding on the traffic tolerance of experimental hybrid bermudagrasses is needed. Data will help turfgrass breeders and athletic field managers determine if these selections are suitable for use on athletic fields. Thus, the objective of this research was to evaluate the traffic tolerance of five experimental and three commercially available bermudagrass varieties maintained under two overseeding and mowing regimens.

\section{Materials and methods}

ExPERIMENTAL AREA. Eight hybrid bermudagrasses were established as $16 \times 10$-ft plots at the East Tennessee Research and Education Center
(Knoxville) 23 June 2005 on a tilled Sequatchie silt loam soil (fine-loamy, siliceous, semi active, thermic Humic Hapludult) using $3 \times 3$-inch plugs planted on 12-inch centers. Three commercially available ('TifGrand', 'TifSport', and 'Tifway') and five experimental (Tift 11, 2004-76, 200477, 2004-78, and 2004-83) hybrid bermudagrasses were evaluated. Plots were irrigated to prevent the onset of moisture stress (as determined visually by the primary investigator) and fertilized with ammonium nitrate $(34 \mathrm{~N}-0 \mathrm{P}-0 \mathrm{~K})$ at $1 \mathrm{lb} / 1000 \mathrm{ft}^{2}$ nitrogen $(\mathrm{N})$ per month from May through September. During October and November, nutrients were supplied using a complete fertilizer $(24 \mathrm{~N}-$ $2.6 \mathrm{P}-9.9 \mathrm{~K}$ ) at $0.5 \mathrm{lb} / 1000 \mathrm{ft}^{2} \mathrm{~N}$ per month. Plots were allowed to mature for 13 months before initiating research.

This study was repeated in time with the same plots used in both 2006 and 2007. Once all data had been collected from the 2006 study, all plots were treated with trifloxysulfuron (Monument 75 WG; Syngenta Crop Protection, Greensboro, NC) at 0.53 $\mathrm{oz} / \mathrm{acre}$ to remove any overseeded perennial ryegrass present. This herbicide was applied with a nonionic surfactant (Activator-90; Loveland Products, Greeley, CO) at $0.25 \% \mathrm{v} / \mathrm{v}$. Turfgrass cover on all plots measured 100\% when simulated traffic was initiated in 2007.

Treatments evaluated. The experimental design was a randomized complete block, split-split plot design, with three replications. Bermudagrass served as the whole plot treatment, mowing regime served as the subplot treatment, and the overseeding regime served as the sub-subplot treatment. Two mowing regimes were evaluated until traffic simulation began: traditional mowing (TM) and mowing + grooming (MG). The TM regime consisted of mowing three times per week with a Jacobsen reel mower (Textron, Charlotte, NC) set to 0.87inch height. The MG regime consisted of mowing three times per week with same reel mower (equipped with grooming blades) at 0.87 inches and grooming to a depth of 0.10 inch below the bench set mowing height. These mowing regimes have been used by other researchers evaluating bermudagrass traffic tolerance (Thoms et al., 2011).
The two overseeding regimes consisted of no overseeding and overseeding with perennial ryegrass $(33 \%$ 'All Star 2', 33\% 'Derby Xtreme', and $33 \%$ 'Top Hat 2') at $12 \mathrm{lb} / 1000 \mathrm{ft}^{2}$ of pure live seed (PLS = percent germination $\times$ percent purity $\times 100)$ on 20 Sept. 2006 and 1 Oct. 2007. Each mowing regime was applied until traffic simulation began on 25 Aug. 2006 and 28 Aug. 2007. After this date, all plots were mowed three times per week at 0.87 inches with the same reel mower.

Traffic simulation was applied using the CTS, a walk-behind core cultivation unit modified with feet attached to each of the four core heads. These feet are built using rubber tires and four bolts to act as studs (i.e., cleats) that strike the surface, creating the dynamic forces characteristic of athletic field traffic (Henderson et al., 2005). The CTS differs from the BTS that has been used by several researchers evaluating traffic tolerance (Dunn et al., 1993; McNitt, 2005; McNitt and Landschoot, 2001; Minner and Valverde, 2005; Sorochan et al., 2005). The BTS contains a frame equipped with two cleated rollers, turning at unequal speeds, connected by a chain and sprockets pulled by a small tractor unit (Cockerham and Brinkman, 1989). The CTS and the BTS produce a similar number of cleat marks (667 and 603 cleat marks $/ \mathrm{m}^{2}$, respectively) and total ground force (6940 and $5128 \mathrm{~N}$, respectively). However, the CTS has been shown to generate more force per unit area than the BTS because of the differences in surface area $\left(1355 \mathrm{~mm}^{2}\right.$ for the CTS compared with $3484 \mathrm{~mm}^{2}$ for the BTS). Researchers have concluded that the CTS produces stress that may be more representative of that occurring on highly trafficked athletic fields (Henderson et al., 2005; Vanini et al., 2007).

Plots were subjected to four CTS passes per week beginning on 25 Aug. 2006 and 28 Aug. 2007. Two passes with the CTS have been reported to simulate the effects of one NCAA football game (Henderson et al., 2005). A total of 20 simulated events (i.e., 40 CTS passes) were applied each year. Each year, CTS passes were not applied the week following perennial ryegrass overseeding to facilitate seed germination and seedling emergence. 
DATA COLLECTION AND ANALYSIS. Traffic tolerance was quantified using measurements of turfgrass cover following each application of simulated traffic. Turfgrass cover was assessed using DIA according to the methods of Karcher and Richardson (2005). Digital images of each plot were taken with a camera (G5; Canon, Tokyo) mounted on a $0.28-\mathrm{m}^{2}$ enclosed light box with four $40-\mathrm{W}$ spring lamps (TCP; Lighthouse Supply, Bristol, VA), powered by a $600 \mathrm{HD}$ Power Pack® (Xantrex; Xantrex Technology, Bristol, VA). The images were then analyzed using SigmaScan Pro ${ }^{\odot}$ (version 5.0; IBM Corp., Armonk, NY) which calculates turfgrass cover by dividing the number of green pixels (determined by a set range for hue and saturation) in each image by the total number of pixels $(307,200)$ in each image.

Statistical analysis was performed with mixed model analysis of variance in SAS (version 9.1.3; SAS Institute, Cary, NC). A significant year-bytreatment interaction was detected in turfgrass cover data; therefore, data from each year were analyzed and are presented individually. Fisher's protected least significant difference values $(P \leq 0.05)$ were used to compare treatment means.

\section{Results and discussion}

HybRID BERMUdAgrass PERFORMANCE. A significant variety-byoverseeding interaction was detected in turfgrass cover data on all rating dates after overseeding occurred each year (Table 1). Turfgrass cover only varied due to mowing regime on a single rating date in 2006 and no dates in 2007 (Table 1); therefore, effects as a result of mowing are not presented. These results differ from those of Thoms et al. (2011) who reported that mowing plus regular grooming reduced turfgrass cover of three hybrid and one improved bermudagrass varieties the first year after being established from sod.

TURFGRASS COVER ON NONOVERSEEDED PLOTS. Experimental bermudagrass Tift 11 and the commercially available variety TifGrand yielded turfgrass cover values greater than or equal to 'Tifway' on all rating dates in 2006 and 2007 (Table 2). After 20 simulated traffic events in 2006 , turfgrass cover for Tift 11 and 'TifGrand' ranged

Table 1. Analysis of variance of hybrid bermudagrass turfgrass cover data collected after 5, 10, 15, and 20 simulated traffic events were applied with the Cady traffic simulator in 2006 and 2007 at Knoxville, TN.

\begin{tabular}{|c|c|c|c|c|c|c|c|c|c|}
\hline \multirow[b]{3}{*}{ Treatment } & \multirow[b]{3}{*}{ df } & \multicolumn{8}{|c|}{ Simulated traffic events (no.) } \\
\hline & & \multicolumn{4}{|c|}{2006} & \multicolumn{4}{|c|}{2007} \\
\hline & & 5 & 10 & 15 & 20 & 5 & 10 & 15 & 20 \\
\hline Bermudagrass $(\mathrm{B})^{\mathrm{z}}$ & 7 & ** & * & * & $\mathrm{NS}^{\mathrm{y}}$ & $* * *$ & *** & $* * *$ & *** \\
\hline Error 1 & 14 & - & - & - & - & - & - & - & - \\
\hline Mowing $(\mathrm{M})^{\mathrm{x}}$ & 1 & * & NS & NS & NS & NS & NS & NS & NS \\
\hline $\mathrm{M} \times \mathrm{B}$ & 7 & NS & NS & NS & NS & NS & * & NS & NS \\
\hline Error 2 & 16 & - & - & - & - & - & - & - & - \\
\hline Overseeding $(\mathrm{O})^{\mathrm{w}}$ & 1 & NS & $* * *$ & $* * *$ & $* * *$ & * & *** & $* * *$ & *** \\
\hline $\mathrm{O} \times \mathrm{B}$ & 7 & NS & $* * *$ & $* * *$ & * & NS & *** & $* * *$ & *** \\
\hline $\mathrm{O} \times \mathrm{M}$ & 1 & NS & NS & NS & NS & NS & NS & NS & NS \\
\hline $\mathrm{O} \times \mathrm{M} \times \mathrm{B}$ & 7 & NS & NS & NS & NS & NS & NS & NS & NS \\
\hline Error 3 & 32 & - & - & - & - & - & - & - & - \\
\hline
\end{tabular}

${ }^{2}$ Hybrid bermudagrasses consisted of five experimental lines (2004-76, 2004-83, 2004-78, Tift 11, and 2004-77) and three commercially available selections ('Tifway', 'TifSport', and 'TifGrand').

${ }^{y}$ Not significant at the $P \leq 0.05$ level.

${ }^{\mathrm{x}}$ Mowing treatments consisted of mowing at height 0.87 inches $(2.210 \mathrm{~cm})$ or mowing at height 0.87 inches + grooming at depth 0.10 inches $(2.540 \mathrm{~mm})$ below the mowing height.

w Overseeding treatments consisted of no overseeding or overseeding with perennial ryegrass at $12 \mathrm{lb} / 1000 \mathrm{ft}^{2}$ $\left(58.6 \mathrm{~g} \cdot \mathrm{m}^{-2}\right)$ pure live seed $(\mathrm{PLS}=$ percent germination $\times$ percent purity $\times 100)$. Overseeding occurred after six simulated traffic events on 20 Sept. 2006 and 1 Oct. 2007

${ }^{*}, * *, * * *$ Significant at the $0.05,0.01$, and 0.001 levels, respectively.

from $27 \%$ to $28 \%$, compared with $21 \%$ for 'Tifway'. Similarly, turfgrass cover after 20 simulated traffic events in 2007 measured 72\% for 'Tifway' compared with $68 \%$ to $76 \%$ for Tift 11 and 'TifGrand', respectively. Experimental bermudagrasses 2004-77 and 2004-78 yielded turfgrass cover values similar to 'Tifway' except for a single date in 2007 (Table 2). Turfgrass cover values for the experimental bermudagrass 2004-83 were not significantly greater than the lowest value on all rating dates each year, with turfgrass cover values of $14 \%$ and $58 \%$ after 20 simulated events had been applied in 2006 and 2007, respectively. Inconsistent relationships in turfgrass cover were detected between 'TifSport', 'Tifway', and 2004-76 each year.

Although a direct statistical comparison could not be made, turfgrass cover values in 2006 tended to be lower than those in 2007. For example, turfgrass cover after 20 simulated traffic events in 2006 ranged from $14 \%$ to $34 \%$ compared with $58 \%$ to $79 \%$ in 2007 (Table 2). Differences in turfgrass cover may have been related to air temperature. Average high air temperatures during traffic simulation in 2006 ranged from 20 to $26^{\circ} \mathrm{C}$ compared with 25 to $31^{\circ} \mathrm{C}$ in 2007 . Increased air temperatures in 2007 may have allowed for some degree of recuperation during the traffic simulation period resulting in less pronounced reductions in turfgrass cover.

Turfgrass COVER ON OVERSEEDED PLOTS. Although a direct statistical comparison could not be made, overseeding increased turfgrass cover for all bermudagrasses in both years. In 2006, turfgrass cover after 20 simulated traffic events ranged from $56 \%$ to $70 \%$ on plots receiving overseeding compared with $14 \%$ to $34 \%$ on nonoverseeded plots (Table 2). A similar response was observed in 2007 as well. These findings support the findings of other researchers that perennial ryegrass overseeding improved turfgrass cover on athletic fields subjected to traffic (Cockerham et al., 1993; Deaton and Williams, 2010; Mazur and Wagner, 1987; Thoms et al., 2011).

When overseeded, few statistically significant differences in turfgrass cover were detected among bermudagrasses. At the conclusion of the study, each year there was less than a $15 \%$ difference in turfgrass cover between treatments (Table 2). When overseeded with perennial ryegrass, 'TifGrand', 'TifSport', and experimental bermudagrasses 2004-76, 2004-78, and Tift 11 yielded turfgrass cover values similar to 'Tifway' on all rating dates each year. These results differ from those of Deaton and Williams (2010) who reported that overseeding at 546 and $1093 \mathrm{lb} /$ acre of PLS 
Table 2. Digital image analysis for turfgrass cover values of hybrid bermudagrasses subjected to perennial ryegrass overseeding $^{\mathrm{z}}$ after $5,10,15$, and 20 simulated traffic events were applied with the Cady traffic simulator at Knoxville, TN, in 2006 and 2007.

\begin{tabular}{|c|c|c|c|c|c|c|c|c|c|}
\hline \multirow{4}{*}{$\begin{array}{l}\text { Overseeding } \\
\left(1 \mathrm{~b} / 1000 \mathrm{ft}^{2} \text { PLS }\right)^{\mathrm{z}}\end{array}$} & \multirow[b]{4}{*}{ Bermudagrasses } & \multicolumn{8}{|c|}{ Turfgrass cover $(\%)$} \\
\hline & & \multicolumn{4}{|c|}{2006} & \multicolumn{4}{|c|}{2007} \\
\hline & & \multicolumn{8}{|c|}{ Simulated traffic events (no.) } \\
\hline & & 5 & 10 & 15 & 20 & 5 & 10 & 15 & 20 \\
\hline \multirow[t]{6}{*}{0} & 2004-76 & $74 \mathrm{bcd}^{y}$ & $58 \mathrm{~cd}$ & $32 \mathrm{~cd}$ & $15 \mathrm{~cd}$ & $91 \mathrm{a}$ & $61 \mathrm{ab}$ & $68 c$ & $68 \mathrm{ab}$ \\
\hline & $2004-77$ & $86 \mathrm{ab}$ & $77 \mathrm{ab}$ & $41 \mathrm{bc}$ & $18 \mathrm{bcd}$ & $82 \mathrm{abc}$ & $66 \mathrm{ab}$ & $78 \mathrm{abc}$ & $60 \mathrm{~b}$ \\
\hline & $2004-78$ & 89 a & $79 \mathrm{a}$ & $68 \mathrm{a}$ & $34 \mathrm{a}$ & $70 \mathrm{~cd}$ & $70 \mathrm{a}$ & $85 a$ & $73 \mathrm{a}$ \\
\hline & 'TifSport' & $69 \mathrm{~cd}$ & $59 \mathrm{~cd}$ & $32 \mathrm{~cd}$ & $15 \mathrm{~cd}$ & 76 bcd & $50 \mathrm{c}$ & $52 \mathrm{~d}$ & $59 \mathrm{~b}$ \\
\hline & Tift 11 & $88 \mathrm{a}$ & $79 \mathrm{a}$ & $63 a$ & $28 \mathrm{ab}$ & 74 bcd & $67 \mathrm{ab}$ & $80 \mathrm{ab}$ & $68 \mathrm{ab}$ \\
\hline & 'Tifway’ & $81 \mathrm{abc}$ & $67 b c$ & $44 \mathrm{bc}$ & $21 \mathrm{bcd}$ & $84 \mathrm{ab}$ & $59 \mathrm{bc}$ & $71 \mathrm{bc}$ & $72 \mathrm{a}$ \\
\hline \multirow[t]{4}{*}{12} & $2004-76$ & $74 \mathrm{bc}$ & $88 \mathrm{ab}$ & $87 \mathrm{a}$ & $68 \mathrm{ab}$ & $90 \mathrm{a}$ & $84 \mathrm{a}$ & $88 \mathrm{ab}$ & $93 \mathrm{a}$ \\
\hline & 'TifSport' & $74 \mathrm{bc}$ & $88 \mathrm{ab}$ & $82 \mathrm{ab}$ & $64 \mathrm{ab}$ & $77 \mathrm{bc}$ & $77 \mathrm{ab}$ & $80 \mathrm{bc}$ & $90 \mathrm{a}$ \\
\hline & Tift 11 & $90 \mathrm{a}$ & $88 \mathrm{ab}$ & $91 \mathrm{a}$ & $68 \mathrm{ab}$ & $71 \mathrm{~cd}$ & $79 \mathrm{ab}$ & $90 \mathrm{ab}$ & $91 \mathrm{a}$ \\
\hline & 'Tifway' & $80 \mathrm{ab}$ & $90 \mathrm{a}$ & $88 \mathrm{a}$ & $70 \mathrm{a}$ & $82 \mathrm{abc}$ & $84 \mathrm{a}$ & $89 \mathrm{ab}$ & $93 \mathrm{a}$ \\
\hline
\end{tabular}

${ }^{\mathrm{z}}$ Overseeding occurred after six simulated events on 20 Sept. 2006 and 1 Oct. 2007 . Pure live seed $($ PLS $=$ percent purity $\times$ percent germination $\times 100)$; lb $/$ acre $=$ $1.1209 \mathrm{~kg} \mathrm{ha}^{-1}$

y'Within a column, values followed by the same letter are not significantly different from one another according to Fisher's protected least significance difference test at $P<0.05$.

improved turfgrass cover to a greater extent on coarse textured varieties exhibiting lower traffic tolerance (Quickstand and Yukon) than varieties such as Riviera and Tifway. In the current study, no differences in traffic tolerance (measured as turfgrass cover) were detected between 'TifGrand', Tift 11, 2004-76, and 'Tifway' after 20 simulated traffic events each year.

Results from this study illustrate that 'TifGrand' and the experimental bermudagrasses Tift 11, 2004-78, and 2004-76 exhibit traffic tolerance similar to 'Tifway'. Thus, 'TifGrand', Tift 11, 2004-78, and 2004-76 may be new options for use on hybrid bermudagrass athletic fields. Considering that 'TifGrand' has been reported to offer improved quality in situations of low light, it may be best suited for use on athletic fields affected with shade. Overseeding improved turfgrass cover retention under simulated traffic for all bermudagrasses, as few statistically significant differences were observed between overseeded selections each year. Additional research is needed to determine the mechanisms associated with bermudagrass traffic tolerance to aid turfgrass breeders in developing bermudagrasses for use on athletic fields.

\section{Literature cited}

Baldwin, C.M., H. Liu, and L.B. McCarty. 2008. Diversity of 42 bermudagrass cultivars in a reduced light environment. Acta Hort. 783:147-157.

Beard, J.B. 1973. Turfgrass: Science and culture. Prentice Hall, New York.

Brosnan, J.T. and J. Deputy. 2009. Preliminary observations on the traffic tolerance of four seashore paspalum cultivars compared to hybrid bermudagrass. HortTechnology 19:423-426.

Christians, N. 1998. Fundamentals of turfgrass management. Ann Arbor Press, Chelsea, MI.

Cockerham, R.N. and G. Wiecko. 1989. Soil compaction and wear stresses on turfgrass: Future research directions. 6th Intl. Turfgrass Res. Conf., Tokyo. p. 3742.

Cockerham, S.T. 1989. Cleated-shoe traffic concentration on a football field. California Turfgrass Cult. 39:11-12.

Cockerham, S.T. and D.J. Brinkman. 1989. A simulator for cleated-shoe sports traffic on turfgrass research plots. California Turfgrass Cult. 39:9-10.

Cockerham, S.T., V.A. Gibeault, and R.A. Khan. 1993. Alteration of sports fields characteristics using management. Intl. Turfgrass Soc. Res. J. 7:182-191.
Deaton, M.T. and D.W. Williams. 2010. Overseeding and trinexapac-ethyl effects on tolerance to simulated traffic of four bermudagrass cultivars grown as a sandbased athletic field. HortTechnology 20: 724-729.

Duble, R.L. 1996. Turfgrasses: Their management and use in the southern zone. 2nd ed. Texas A\&M Univ. Press, College Station, TX.

Dunn, J.H., S.S. Burghrara, and B.S. Fresenburg. 1993. Traffic tolerance among cultivars of kentucky bluegrass, tall fescue, and perennial ryegrass. Intl. Turfgrass Soc. Res. J. 7:687-694.

Dunnivant, W.E. 2008. Grooming frequency and spacing effects on a TifEagle bermudagrass putting green. Auburn Univ., Auburn, AL, M.S. Thesis.

Goddard, M.J.R., J.C. Sorochan, J.S. McElroy, D.E. Karcher, and J.W. Landreth. 2008. The effects of crumb rubber topdressing on hybrid kentucky bluegrass and bermudagrass athletic fields in the transition zone. Crop Sci. 48:2003-2009.

Hanna, W.W., K. Braman, and B. Schwartz. 2010. 'ST-5', A shade tolerant turf bermudagrass. HortScience 45:132-134.

Henderson, J.J., J.L. Lanovaz, J.N. Rogers, III, J.C. Sorochan, and J.T. Vanini. 2005. A new apparatus to stimulate athletic field traffic: The Cady traffic simulator. Agron. J. 97:1153-1157. 


\section{Research Reports}

Karcher, D.E. and M.D. Richardson. 2005. Batch analysis of digital images to evaluate turfgrass characteristics. Crop Sci. 45:1536-1539.

Kopec, D.M., J.J. Gilbert, J.H. Walworth, M. Pessarakli, D. Kerr, and J. Spence. 2005. Effects of surface cultural practices on Sea Isle 2000 greens: Less is more when it comes to cultural practices on seashore paspalum greens. Golf Course Mgt. 73:81-84.

Mazur, A.R. and D.F. Wagner. 1987. Influence of aeration, topdressing, and vertical mowing on overseeded bermudagrass putting green turf. HortScience 22:1276-1278.

McCarty, L.B., M.F. Gregg, and J.E. Toler. 2007. Thatch and mat management in an established creeping bentgrass golf green. Agron. J. 99:1530-1537.

McCarty, L.B., M.F. Gregg, J.E. Toler, J.J. Camberato, and H.S. Hill. 2005. Minimizing thatch and mat development in a newly seeded creeping bentgrass golf green. Crop Sci. 45:1529-1535.

McNitt, A.S. 2005. Synthetic turf in the USA trends and issues. Intl. Turfgrass Soc. Res. J. 10:27-33.

McNitt, A.S. and P.S. Landschoot. 2001. The effects of soil reinforcing inclusions in an athletic field rootzone. Intl. Turfgrass Soc. Res. J. 9:565-572.

Minner, D.D. and F.J. Valverde. 2005 The effect of traffic intensity and periodicity on Poa pratensis L. performance. Intl. Turfgrass Soc. Res. J. 10:387-392.

Sorochan, J.C., J.N. Rogers, III, J.C. Stier, and D.E. Karcher. 2005. Determination of optimal mowing height after Poa supina Schrad. under traffic conditions. Intl. Turfgrass Soc. Res. J. 10:436440 .

Thoms, A.W., J.C. Sorochan, J.T. Brosnan, and T.J. Samples. 2011. Perennial ryegrass (Lolium perenne L.) and grooming affect bermudagrass traffic tolerance. Crop Sci. 51:2204-2211.

Trappe, J., A. Patton, and M. Richardson. 2009. Bermudagrass cultivars differ in their traffic tolerance. Arkansas Turfgrass Rpt. 2008:137-140.

Trenholm, L.E., R.R. Duncan, and R.N. Carrow. 1999. Wear tolerance, shoot performance, and spectral reflectance of seashore paspalum and bermudagrass. Crop Sci. 39:1147-1152.

Vanini, J.T., J.J. Henderson, J.C. Sorochan, and J.N. Rogers, III. 2007. Evaluating traffic stress by the Brinkman traffic simulator and Cady traffic simulator on a kentucky bluegrass stand. Crop Sci. 47: 780-784.

Westmoreland, B., K. Steinke, and R. White. 2007. The effect of grooming intervals on warm-season fairway turf with and without overseeding. Proc. Amer. Soc. Agron., Crop Sci. Soc. Amer., Soil Sci. Soc. Amer. Abstr. 12 (abstr.). 